\title{
KONZUMÁCIA MÄSA NA HRADOCH VO VRCHOLNOM STREDOVEKU: PRÍPADOVÁ ŠTÚDIA Z HRADU PEŤUŠA
}

\author{
KATARÍNA ŠIMUNKOVÁ - NOÉMI BELJAK PAŽINOVÁ
}

\begin{abstract}
Abstrakt: Ciel'om je predstavit' a interpretovat' výsledky analýzy faunálnych pozostatkov z vrcholnostredovekého hradu Pet’uša v katastrálnom územi Ostrá Lúka, okres Zvolen. Analyzovaný súbor pochádza z výskumu lokality v rokoch 2011-2017. Osteologické pozostatky tvorilo celkovo 6791 fragmentov s hmotnostou približne 49,3 kg. Pri analýze boli použité kvantifikačné metódy - NISP a MNI. Dominovali domáce druhy (napr. tur domáci, sviňa domáca, ovca/koza atd.) nad lovenými (napr. srnec hôrny, jeleň obyčajný, zajac polný atd'). Zároveň tu boli zachytené aj pozostatky komenzálnych živočichov a malakofauna. Na lokalite sa objavuje hlavne bežný kuchynský odpad so stopami po sekani a rezaní, ale zachytené boli aj stopy po zuboch hlodavcov či mäsožravcov. Na niektorých kostiach boli zaznamenané aj stopy po pôsobení žiaru, predovšetkým na domácich druhoch (ovca/koza, sviňa domáca, tur domáci), vyskytujú sa však aj na kostiach divých druhov (jeleň, srnec). Na lokalite predpokladáme aj spracovanie kostí na polotovary, prípadne ide o odpad z remeselníckej výroby (odštiepky parohoviny, stopy po pílení, vŕtani a pod.).
\end{abstract}

Kl'účové slová: hrad Petuša - archeologický výskum - archeozoológia - 13. až prelom 15. a 16. storočia - stredné Slovensko.

The consumption of meat in castles in the high Middle Ages: A case study from the Pet'uša castle

Abstract: This contribution presents and interprets the results of the analysis of fauna relics from the Pet'uša castle from the high Middle Ages, in the Ostrá Lúka cadastral zone, Zvolen district. The analysed series comes from excavations conducted in 2011-2017. The osteological remains involved 6,791 fragments weighing roughly $49.3 \mathrm{~kg}$. Quantification methods such as NISP and MNI were used for the analysis. The series was dominated by domestic animals (cattle, pig, sheep/goat, etc.), with fewer hunted animals (roe deer, red deer, hare, etc.). There were also remains of commensal species and malacofauna. The location predominantly featured common kitchen waste with traces of chopping and carving, some bone fragments bore traces of rodents' and carnivores' teeth. Some had traces of cooking, especially the bones of domestic animals (sheep/goat, pig, cattle), but even those of wild animals (red deer, roe deer). Apparently, bones were also processed on the site for semi-finished products, or they might have been craftsmen's waste (splinters of antlers, traces of sawing, drilling, etc.).

Key words: Pet'uša castle - archaeological research - archaeozoology-13th century -15th/16th century - central Slovakia.

\section{1 Úvod}

Zaniknutý vrcholnostredoveký hrad Pet'uša sa nachádza na strednom Slovensku, ned’aleko okresného mesta Zvolen, v katastri obce Ostrá Lúka. Archeologický výskum na hrade realizovala v rokoch 2011-2017 Katedra archeológie Univerzity Konštantína Filozofa v Nitre. Preskúmané boli rozsiahle časti nádvoria, hradby opevnenia, priekopa a okolité terasy; celkovo plocha s rozsahom vyše $150 \mathrm{~m}^{2}$. Prostredníctvom analýzy terénnych situácií, hnutel'ných i nehnutel'ných nálezov, ako aj pomocou archívno-historického výskumu sa podarilo spresnit' datovanie hradu (koniec 13. storočia - 15./16. storočie), jeho stavebno-historický vývoj a poukázat' na jeho možnú funkciu, resp. využitie (Beljak Pažinová 2017; Beljak Pažinová-Ragač 2018).

Zámerom príspevku je predstavit' často opomenutý archeologický prameň, a to osteologické zvieracie pozostatky objavené na nádvorí hradu Pet’uša. Prostredníctvom komplexnej 
analýzy tohto rozmanitého prameňa je našou snahou priblížit' stravu na hrade a jej vypovedacie možnosti.

\section{Osteologický materiál a metodika jeho spracovania}

Osteologický materiál bol získaný ručne vol’ným okom a preosievaním, sediment nebol preplavovaný. Datovanie materiálu bolo určené výlučne na základe časového určenia sprievodných archeologických nálezov. Celkovo bolo analyzovaných 6791 kostí a ich fragmentov s hmotnost'ou približne 49,3 kg. Do skupín neurčitel'ných druhov (Indet.), resp. do skupiny vel'ký, stredný a malý cicavec, bolo zaradených 4012 kusov (59\%) s hmotnost'ou 14,3 kg (29\%).

Anatomická determinácia zvieracích kostí a zároveň i určovanie taxónov boli urobené na základe dostupných publikácií veterinárnych lekárov, anatómov a archeozoológov (AdamsCrabtree 2008; Bocheński-Tomek 2000; 2009; 2009a; France 2009; Kolda 1951; Popesko 2007; Schmid 1972) a s využitím vlastnej porovnávacej zbierky a porovnávacej zbierky ARÚ AV ČR v Prahe. Fragmenty, ktoré nebolo možné jednoznačné zaradit' do druhu, boli zaradené do pomocných kategórií, bežne používaných v archeozoologických prácach: vel'ký cicavec (kôň, hovädzí dobytok, jeleň), stredný cicavec (vel'kost' kozy/ovce, ošípanej, srnca, väčšieho psa a pod.) a malý cicavec (vel'kost' hlodavcov) na základe vel'kosti, váhy a štruktúry fragmentu. Skupina malých prežúvavcov označených ako Ovis/Capra zahŕňa oba druhy podčel'ade Caprinae - ovcu a kozu domácu. Pokial' bolo možné, diferenciácia ich kostí bola uskutočnená podl'a článkov J. Boessnecka (1969), B. J. Adamsa a P. J. Crabtree (2008), P. Halsteada a P. Collinsovej (1995; 2002) a S. Paynea (1973).

Pokial' to stav zachovania kostí a fragmentov dovol'oval, boli merané osteometrické údaje podla A. von den Driesch (1976) a na základe týchto mier boli následne vypočítané kohútikové výšky zvierat (napr. Vitt 1952; Fock 1966, ref. von den Driesch-Boessneck 1974; Teichert 1969; Harcourt 1974). Na určenie približného veku zvierat boli použité obe metódy: podla epifýzového zrastenia (Zoetis et al. 2003; Reitz-Wing 2008) aj podl'a erupcie zubov a ich obrusu (Grant 1982; Payne 1973; 1987; Hillson 2005).

Podla determinovaných anatomických častí jednotlivých zvierat bola určená i kvalita mäsa, a to na základe prác V. Párala, Z. Měchurovej a M. Riedlovej (1995) a V. Párala a M. Pyszka (2011).

Základné kvantifikačné metódy použité pri analýze boli NISP, MNI a hmotnost', ktoré vychádzali zo štandardných metód (Klein-Cruz-Uribe 1984; Kyselý 2004; Reitz-Wing 2008).

V kvantifikačnej metóde NISP (počet identifikovaných fragmentov/kostí) bola za jednotku považovaná každá jednotlivá kost' alebo jej fragment, aj napriek tomu, že niektoré bolo možné priradit' a zlepit' do jednej kosti (napríklad nezrastená epifýza, určite patriaca k danej diafýze, označená ako samostatná jednotka). Pri čel'ustiach bola za jednotku považovaná dolná alebo horná čel'ust' spolu so zubami, ktoré v nej boli zakotvené.

Hodnoty MNI (minimálny počet jedincov) boli vypočítané na základe početnosti anatomického prvku s prihliadnutím na určenie strany, v kombinácii s fragmentárnostou a s vekovým určením jednotlivých druhov. Fragmenty patriace evidentne k sebe boli označené ako jedna jednotka.

\section{Výsledky}

\section{Zastúpenie druhov}

Na hrade Pet'uša boli identifikované nasledovné taxóny zvierat: tur domáci (Bos taurus), pes (Canis familiaris), koza (Capra hircus), kôň domáci (Equus caballus), ovca (Ovis aries) a sviňa domáca (Sus domesticus), srnec hôrny (Capreolus capreolus), jeleň obyčajný (Cervus elapheus), mačka divá (Felis silvestris), diviak lesný (Sus scrofa), zajac pol'ný (Lepus europaeus), veverička hrdzavá (Sciurus vulgaris), medved' hnedý (Ursus arctos), plch záhradný (Eliomys quercinus), potkan (Rattus sp.). Vtáky boli určené nasledovne: kura domáca (Gallus domesticus), 
holub domáci (Columbal. domestica), pravdepodobne hus domáca (Anser domesticus?), z divých druhov vtákov boli určené kavka tmavá (Corvus monedula), sojka obyčajná (Garrulus glandarius), jarabica pol'ná (Perdix perdix), bažant obyčajný (Phasianus colchicus), straka obyčajná (Pica pica), hluchán̆ hôrny (Tetrao urogallus), chriaštel' (Rallus cf.). Druhovo bližšie neurčené kosti boli zaradené do skupín: ovca/koza (Ovis/Capra), vtáky: sokolovité (Falco sp.), d’atlovité (Picoides-Dendrocopos sp.), drozdovité (Turdidae), neurčené vtáky (Aves sp.), ryby (Pisces sp.), psovité (Canidae sp.) a hlodavce (Rodentia sp.). V materiáli bola zaznamenaná aj malakofauna, z ktorej sa podarilo určit' triedu Gastropoda s druhmi slimák záhradný (Helix pomatia), bacul'ka obyčajná (Bradybaena fruticum) a čel'ad' vretienkových slimákov (Clausiliidae sp.).

$\mathrm{V}$ analyzovanom materiáli z hradu Pet'uša výrazne prevládali domáce druhy. Tie tvorili približne $68 \%$ (1 $890 \mathrm{ks}$; graf 1). Hmotnost' fragmentov identifikovaných domácich druhov bola približne $22,7 \mathrm{~kg}$ (cca $46 \%$ celkovej hmotnosti vzorky).

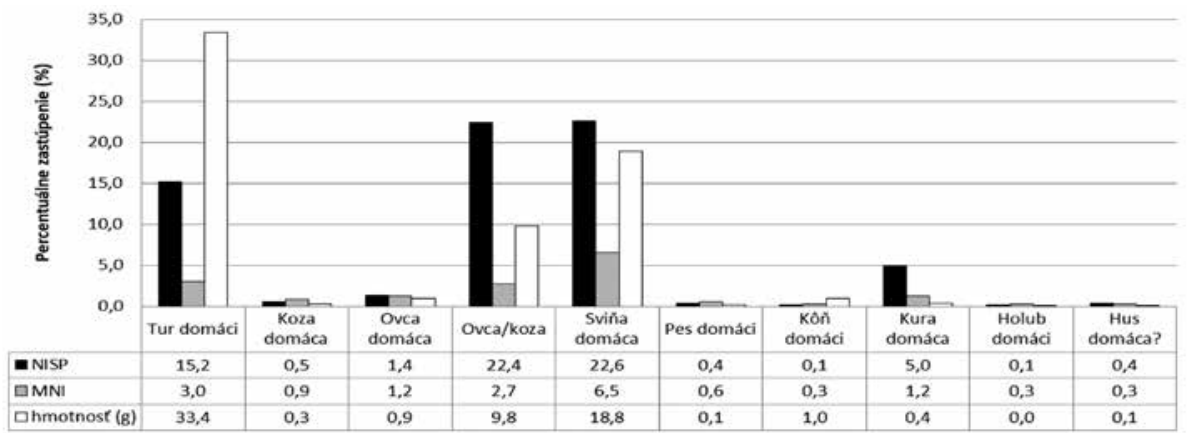

Graf 1. Hrad Pet’uša. Relatívne percentuálne zastúpenie v skupine domácich druhov zvierat (NISP, MNI, hmotnost'). Diagramm 1. Burg Pet'uša. Relatives prozentuales Vorkommen in der Gruppe Haustierarten (NISP, MNI, Gewicht).

V metóde NISP prevažovala kategória ovca/koza (vrátane rozlíšených druhov kozy domácej a ovce domácej), na druhom mieste bola sviňa domáca a na tret’om tur domáci. Hmotnostne bolo toto poradie opačné, teda prevažoval tur domáci, nasledovala sviňa domáca a nakoniec kategória ovca/koza vrátane určených druhov koza domáca a ovca domáca. Pokial’ ide o minimálny počet jedincov (MNI), na prvom mieste bola sviňa domáca, a to až 22 jedincami. Nasledovala ovca/koza (vrátane 3 kôz a 4 oviec bolo identifikovaných dohromady minimálne 16 jedincov) a tur domáci s minimálne 10 jedincami.

Z divých druhov stavovcov dominovalo zastúpenie jeleňa obyčajného (tab. 1). Tu je však potrebné poznamenat', že hodnotu NISP výrazne ovplyvnili fragmenty parohov, ktoré sa na lokalite našli vo forme odštiepkov (118ks). I napriek týmto výhradám tento druh prevažuje počtom fragmentov kostí nad ostatnými. V metóde NISP po ňom nasleduje srnec hôrny a z určených druhov je na tretom mieste medved' hnedý (tab. 1). To isté platí aj pri kvantifikačnej metóde MNI, v ktorej je jeleň zastúpený minimálne štyrmi jedincami, srnec hôrny tromi jedincami a medved' hnedý spolu s veveričkou hrdzavou po dvoch jedincoch. Prvé dve miesta ostávajú nezmenené aj v porovnaní hmotnosti určených fragmentov kostí, len na tretom mieste sa v tomto prípade objavuje diviak lesný.

\section{Rozmery domácich zvierat}

Z osteologického materiálu sa dalo vypočítat' niekol'ko kohútikových výšok určitých zvierat. Tie sa až na niektoré výnimky nevymykajú bežným priemerom známym zo stredoveku.

Výška tura domáceho bola vypočítaná na základe podpätovej kosti (metatarsus). Daný jedinec meral približne $116,6 \mathrm{~cm}$. To zodpovedá bežne nachádzanej výške zvierat $\mathrm{v}$ stredovekej Európe, ktorá v Čechách a na Morave dosahovala rozpätie 91-132 cm, v Nemecku a Švajčiarsku 


\begin{tabular}{|c|c|c|c|c|c|}
\hline & Druh & Druh (latinský názov) & NISP & MNI & hmotnost' (g) \\
\hline \multirow{10}{*}{ 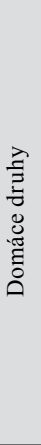 } & Tur domáci & Bos taurus & 422 & 10 & 11696,51 \\
\hline & Koza domáca & Capra hircus & 14 & 3 & 100 \\
\hline & Ovca domáca & Ovis aries & 38 & 4 & 327,22 \\
\hline & Ovca/koza & Ovis/Capra & 622 & 9 & 3421,18 \\
\hline & Sviňa domáca & Sus domesticus & 629 & 22 & 6593,39 \\
\hline & Pes domáci & Canis familiaris & 10 & 2 & 49,98 \\
\hline & Kôň domáci & Equus caballus & 3 & 1 & 333,36 \\
\hline & Kura domáca & Gallus domesticus & 138 & 4 & 132,05 \\
\hline & Holub domáci & Columba l. domestica & 3 & 1 & 0,71 \\
\hline & Hus domáca? & Anser domesticus? & 11 & 1 & 26,23 \\
\hline \multirow{8}{*}{ 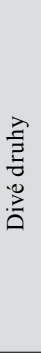 } & Psovité & Canidae sp. & 12 & 1 & 57,36 \\
\hline & Srnec hôrny & Capreolus capreolus & 62 & 3 & 1074,91 \\
\hline & Jeleň obyčajný & Cervus elapheus & 461 & 4 & 10879,14 \\
\hline & Mačka divá & Felis silvestris & 6 & 1 & 57,04 \\
\hline & Zajac pol’ný & Lepus europaeus & 6 & 1 & 9,05 \\
\hline & Veverička hrdzavá & Sciurus vulgaris & 5 & 1 & 2,24 \\
\hline & Diviak lesný & Sus scrofa & 7 & 1 & 108,91 \\
\hline & Medved' hnedý & Ursus arctos & 8 & 2 & 84,48 \\
\hline \multirow{3}{*}{ 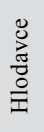 } & Plch záhradný & Eliomys quercinus & 1 & 1 & 0,28 \\
\hline & Potkan & Rattus sp. & 7 & 2 & 2,09 \\
\hline & Hlodavce & Rodentia sp. & 10 & 1 & 2,08 \\
\hline \multirow{11}{*}{$\frac{\vec{a}}{\stackrel{\sigma}{J}}$} & Kavka tmavá & Corvus monedula & 4 & 1 & 1,57 \\
\hline & Sojka obyčajná & Garrulus glandarius & 1 & 1 & 0,19 \\
\hline & Jarabica pol'ná & Perdix perdix & 1 & 1 & 0,42 \\
\hline & Bažant obyčajný & Phasianus colchicus & 5 & 1 & 3,47 \\
\hline & Straka obyčajná & Pica pica & 1 & 1 & 0,22 \\
\hline & Chriaštel' cf. & Rallus cf. & 1 & 1 & 0,25 \\
\hline & Hlucháň hôrny & Tetrao urogallus & 1 & 1 & 1,96 \\
\hline & Sokolovité & Falco sp. & 12 & 1 & 2,44 \\
\hline & Ďatl'otvaré/Ďatel' sp. & Picoides/Dendrocopos sp. & 1 & 1 & 0,24 \\
\hline & Drozdovité & Turdidae & 1 & 1 & 0,08 \\
\hline & Vtáky sp. & Aves sp. & 19 & 10 & 13,16 \\
\hline \multirow{5}{*}{ 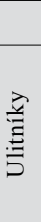 } & Ryby & Pisces sp. & 11 & 1 & 4,38 \\
\hline & Bacul'ka obyčajná & Bradybaena fruticum & 33 & 33 & 1,69 \\
\hline & Vretienkové slimáky & Clausiliidae sp. & 205 & 205 & 8,28 \\
\hline & Slimák záhradný & Helix pomatia & 2 & 2 & 3,75 \\
\hline & Ulitníky & Gastropoda sp. & 6 & 2 & 0,93 \\
\hline & Indet. & & 2217 & & 3997,7 \\
\hline & malý cicavec & & 127 & & 148,91 \\
\hline & stredný cicavec & & 1124 & & 3839,1 \\
\hline & vel'ký cicavec & & 544 & & 6300,71 \\
\hline
\end{tabular}

Tabela 1. Hrad Pet’uša. Kvantifikačná tabul'ka zvieracích druhov.

Tabelle 1. Burg Pet'uša. Quantifikationstabelle der Tierarten. 
100-127 cm, v Pol’sku 92-127 cm (pozri Nývltová Fišáková-Procházka-Sůvová 2016, tam i d’alšia literatúra).

Najviac kohútikových výšok sa podarilo vypočítat' pre ovcu a kozu domácu, a to pre sedem jedincov. Koza domáca merala na základe výpočtov mier z pätových kostí (calcaneus) $62,8 \mathrm{~cm}$ a $66 \mathrm{~cm}$. Výšky pre ovcu domácu boli vypočítané na základe pätovej kosti $60,1 \mathrm{~cm}, 57,1 \mathrm{~cm}$ a na základe celkovej dížky vretennej kosti (radius) $57 \mathrm{~cm}$ a $57,9 \mathrm{~cm}$. Pre kategóriu ovca/koza bola kohútiková výška rovnako vypočítaná z pätovej kosti a jedinec meral približne $65,7 \mathrm{~cm}$.

Pokial' ide o sviňu domácu, taktiež sa neukázali vzhl'adom na výšku zvierat odchýlky od priemeru v stredoveku. Na základe dvoch pätových kostí zvieratá merali $68,7 \mathrm{~cm}$ a $70,9 \mathrm{~cm}$. O niečo vyššie údaje boli vypočítané na základe tretej záprstnej kosti (metacarpus III; $91,4 \mathrm{~cm}$ ) a štvrtej záprstnej kosti (metacarpus IV; až 101,7 cm), avšak tieto údaje sa nemôžu brat' ako ukazovatele výšok. Je známe, že primitívne svine domáce mali dlhšie metapódiá, čo ovplyvňuje výpočty (von den Driesch-Boessneck 1974, 342).

Rozmedzie kohútikovej výšky $69-78,5 \mathrm{~cm}$ bolo potvrdené aj v stredovekom meste Glanzenberg v Banskej Štiavnici (Bielichová-Labuda 2017, 39). Vo vrcholnom stredoveku v strednej Európe merali zvieratá od $72 \mathrm{~cm}$ po maximálne $90 \mathrm{~cm}$ (Nývltová Fišáková et al. 2016, tam i d’alšia literatúra).

Na základe celkovej dížky holennej kosti (tibia) jedného z dvoch psov identifikovaných na hrade Pet'uša sa podarilo vypočítat' jeho kohútikovú výšku. Jedinec meral približne $31,3 \mathrm{~cm}$ a patrí teda do menších stredných plemien. Pokial' ide o obdobie 13.-15. storočia, psy dosahovali rôznych výšok, avšak maximum sa blíži k 70 cm (Doll 2003, 104-108).

\section{Jatočný vek domácich zvierat a kvalita mäsa}

Podl'a určenia veku boli domáce zvieratá väčšinou zabíjané vo svojom jatočnom veku (graf 2). Celkovo prevažuje kategória adultus, a to až $50 \%$. Na druhej strane je pomerne vysoké zastúpenie i kategórie maturus, teda starších zvierat (18,8\%), spolu s kategóriou juvenis $(18,8 \%)$ a subadultus $(2,5 \%)$.

Kategória juvenis nebola zachytená u tura domáceho, zato však bola zachytená u svín domácich, kôz a oviec domácich (graf 2). U tura domáceho prevažovali staršie zvieratá, pričom tel'atá sa tu neobjavili vôbec. U svíň domácich prevažovali práve zvieratá dospelé a nasledovali ich zástupcovia kategórie juvenis, čo môže byt' spôsobené aj tým, že jatočný vek prasiat sa pohybuje okolo 1-2 rokov a stádo sa obmieňalo pomerne rýchlo. U oviec a kôz domácich (vrátane

\begin{tabular}{|c|c|c|c|c|c|}
\hline 14 & & & & & \\
\hline $\begin{array}{l}12 \\
10\end{array}$ & & & & & \\
\hline 8 & & & & & \\
\hline 6 & & & & & \\
\hline 4 & & & & & \\
\hline $\begin{array}{l}2 \\
0\end{array}$ & & & $\square$ & a & \\
\hline & Tur domáci & $\begin{array}{l}\text { Sviňa } \\
\text { domáca }\end{array}$ & $\begin{array}{c}\text { Koza } \\
\text { domáca }\end{array}$ & $\begin{array}{c}\text { Ovca } \\
\text { domáca }\end{array}$ & Ovca/koza \\
\hline Juvenus & 0 & 4 & 2 & 1 & 2 \\
\hline$\square$ Subadultus & 3 & 1 & 0 & 0 & 2 \\
\hline$\square$ Adultus & 3 & 16 & 1 & 2 & 2 \\
\hline$\square$ Maturus & 4 & 1 & 0 & 1 & 3 \\
\hline
\end{tabular}

Graf 2. Hrad Pet'uša. Relatívne vekové kategórie vybraných domácich zvierat v čase porážky/smrti. Diagramm 2. Burg Pet'uša. Relative Alterskategorie ausgewählter Haustierarten zum Schlacht-/Todeszeitpunkt. 
samostatných skupín ovce domácej a kozy) prevládajú spoločne staré zvieratá (kategória maturus $-36 \%$ ), pričom na druhom mieste je kategória juvenis $(29 \%)$. Z tohto profilu by sa dalo uvažovat' o chove oviec/kôz na vlnu a mlieko, avšak treba vziat' do úvahy aj to, že spracovaný materiál pochádza pravdepodobne zo strážneho hradu. Posádka skôr t’ažila z dávok z okolitých dedín ako z vlastného hospodárstva, a preto je možné, že sa ako strava vojakom dostávali staršie zvieratá, pričom jahňacie a mladé prasatá sa tu nachádzajú vo výraznej menšine.

Nájdené kosti boli roztriedené aj na základe množstva svaloviny obklopujúcej jednotlivé anatomické prvky. Kvalita mäsa A (najkvalitnejšie mäso) je tvorená svalovinou stehna, chrbta, pleca a krku; kvalita mäsa B patrí kostiam hrudníka, predlaktia a kolena; a kvalitu C predstavujú distálne časti končatín (kosti autopódia) a lebky (Páral-Riedlová-Unger 1994, 201; Páral-Měchurová-Riedlová 1995, 419; Páral-Pyszko 2011, 22).

Pomery zastúpenia jednotlivých kvalít mäsa sa odlišujú od jednotlivých druhov. Ako poukazuje graf 3, výrazne prevažuje kvalita mäsa $\mathrm{C}$, teda odpadová čast', a to hlavne u svín domácich, tura domáceho, ale aj u jeleňa (tu je to však spôsobené aj množstvom odštiepkov z parohov) či srnca hôrneho. Jedinú výnimku tvorí kategória ovce/kozy, u ktorej mierne prevažuje kvalita mäsa B. Všeobecne môžeme však poznamenat', že kvalita mäsa $\mathrm{C}$ tvorí až 53 \% z pozorovaných druhov, kvalita B má $25 \%$ a kvalita A $22 \%$. Tento výsledok poukazuje na skutočnost', že obyvatelia na hrade Pet'uša konzumovali častejšie mäso horšej kvality.

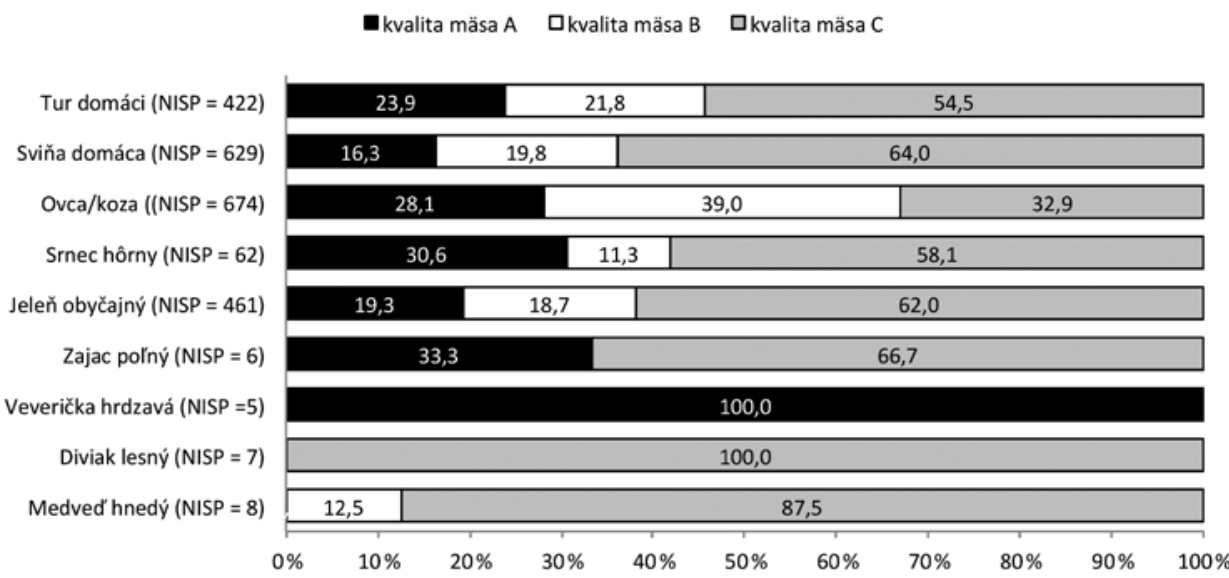

Graf 3. Hrad Pet'uša. „Kvalita“ konzumovaného mäsa na hrade Pet'uša.

Diagramm 3. Burg Pet'uša. „Qualität“ des konsumierten Fleisches auf Burg Pet'uša.

\section{Mäsiarske a iné zásahy na kostiach}

V rámci osteologickej analýzy boli zaznamenané aj mechanické zásahy na kostiach spôsobené l'udskou činnost’ou, a to sekanie, rezanie a pílenie (graf 4). V tomto prípade sme vyňali zo štatistického vyhodnotenia odštiepky z parohoviny patriace jeleňovi obyčajnému kvôli umelému nadhodnoteniu druhu.

Stopy sekania nieslo na sebe 285 fragmentov (4,2\%), a to predovšetkým na rebrách $(112 \mathrm{ks})$, dlhých kostiach $(66 \mathrm{ks})$ a lopatkách $(25 \mathrm{ks})$. Ďalej boli zaznamenané na stavcoch, malých kostiach končatín (napr. talus, calcaneus, články prstov a pod.), lebke, dolných čel'ustiach, panve a krížovej kosti. Šlo o kosti tura domáceho, svine domácej, ovce a kozy domácej, no zároveň aj o divé druhy, a to jeleňa obyčajného, srnca hôrneho a diviaka lesného. Sekanie bolo zachytené aj na bedrovo-krížovej kosti (synsacrum) bližšie neidentifikovaného vtáka. 


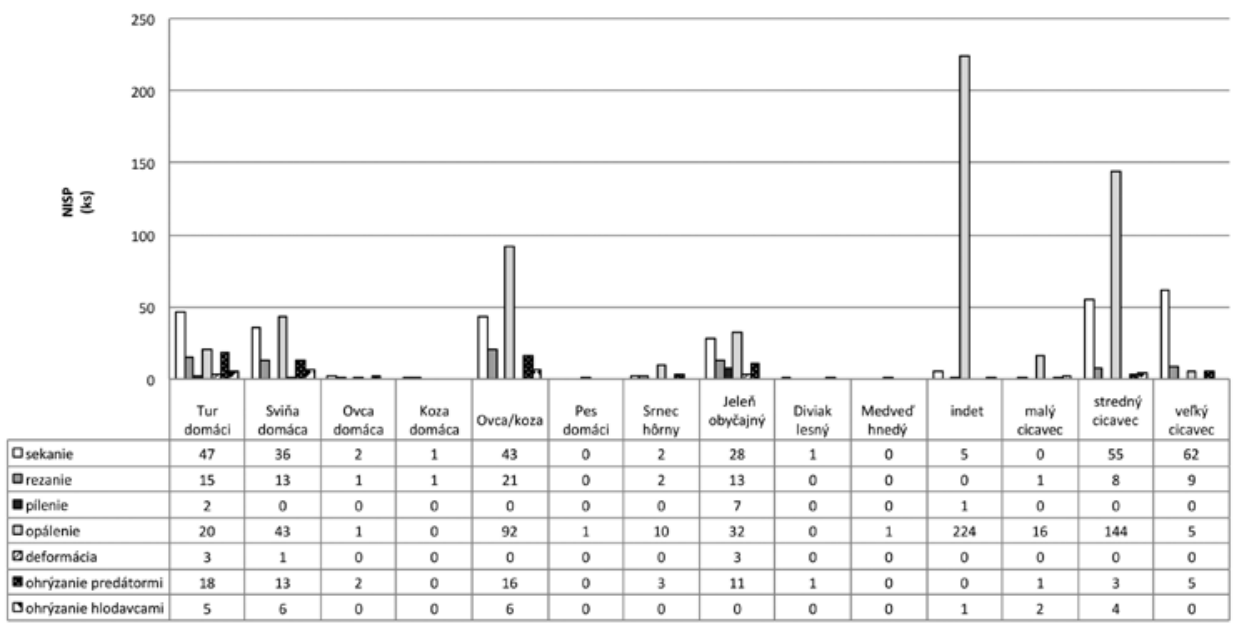

Graf 4. Hrad Pet'uša. Zásahy na zvieracích kostiach.

Diagramm 4. Burg Pet'uša. Eingriffe an Tierknochen.

Rezanie bolo zistené dohromady na 69 fragmentoch, a to hlavne na rebrách ( $22 \mathrm{ks})$, dlhých kostiach (12 ks) a malých kostiach končatín $(9 \mathrm{ks})$, no našli sa aj na kostiach lebky, hornej a dolnej čel'usti, stavcoch, panve, rohu a parohoch pochádzajúcich z tura domáceho, svine domácej, ovce, kozy, srnca hôrneho a jeleňa obyčajného. Tieto stopy by nám mohli naznačovat' bud' postupy pri st’ahovaní kože zvierat a ich porciovanie, alebo jemnejšie spracovávanie mäsa na kuchynské účely. V prípade parohov môžeme uvažovat' o ich remeselnom opracovaní.

Do mechanických zásahov na kostiach patrí aj pílenie. To sa našlo na 10 fragmentoch, $\mathrm{z}$ toho dva fragmenty patrili turovi domácemu (stavec a metacarpus), sedem fragmentov parohov jeleňa obyčajného a jeden fragment dlhej kosti bližšie neurčeného stavovca.

Na kostiach boli spozorované aj stopy po obhrýzaní, a to nielen predátormi, ale aj hlodavcami. To naznačuje vyhodenie relatívne čerstvej kosti, ku ktorej mohli mat' lahký prístup psy a komenzálne živočíchy.

Na pomerne vel'kom počte fragmentov (až $589 \mathrm{ks}$; 8,7\%) boli zaznamenané stopy po pôsobení ohňa (graf 5). Na základe sfarbenia kostného tkaniva do červena, hneda a hnedočierna bolo až 114 fragmentov vystavených teplotnému rozpätiu $285-525^{\circ} \mathrm{C}$. Do čierna, čiernošeda až čiernobiela, a teda v teplotách v rozmedzí 525 až $645^{\circ} \mathrm{C}$, bolo spálených 44 fragmentov. Pri vysokých teplotách, t. j. od $645^{\circ} \mathrm{C}$ až viac ako $940{ }^{\circ} \mathrm{C}$, bolo spálených 50 fragmentov kostí, na čo poukazuje sfarbenie kostného tkaniva od šedej až do kalcinovanej bielej (Shipman-FosterSchoeninger 1984; Thurzo-Beňuš 2005, 55, 56). Vzhl'adom na anatomické prvky boli zastúpené všetky časti tiel, či už fragmenty lebky, končatín, stavcov. Tu treba upozornit' aj na archeologický kontext, pretože prevažná čast' materiálu pochádzala zo zánikového horizontu požiarového charakteru (šedo-čierna popolovitá vrstva pod sutovým zásypom nádvoria), prípadne z okolia pecí a ohnísk.

\section{Doklady výroby}

Na hrade Pet'uša boli doložené aj stopy po výrobe. Polotovary pochádzali z dlhých kostí ovce, ovce/kozy a vel'kého cicavca, na ktorých boli stopy po vyrezávaní otvoru. Aj na jednej dlhej kosti neidentifikovaného druhu boli zaznamenané stopy po pílení. Najviac dokladov výroby nám nepochybne poskytujú fragmenty parohov jeleňa. Tie boli bud' so stopami po pílení, rezaní alebo sekaní rozdel'ované na väčšie a menšie časti polotovarov $(11 \mathrm{ks})$, alebo, a to vo väčšine prípadov, sa našli vo forme odštiepkov z parohoviny (118ks) ako odpadu z výroby. 


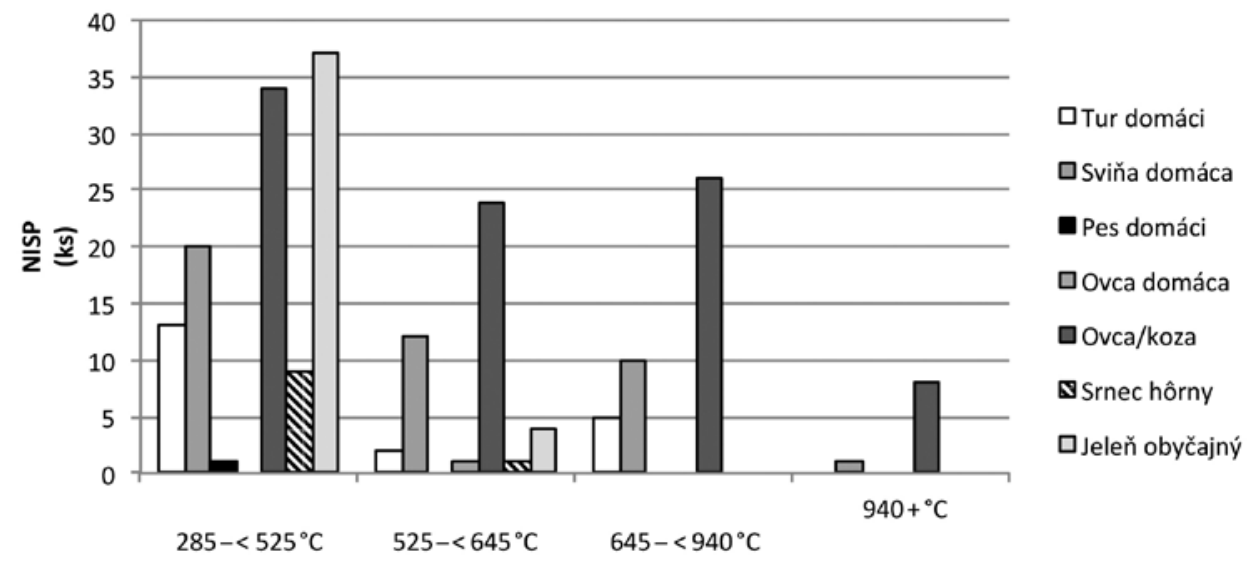

Graf 5. Hrad Pet'uša. Hodnoty rozsahu pôsobenia teplôt na kosti jednotlivých druhov.

Diagramm 5. Burg Pet’uša. Werte bzgl. des Umfangs der Hitzeeinwirkung auf die Knochen der einzelnen Arten.

Objavili sa tu aj dva drobné predmety, a to krehká kostená doštička zdobená koncentrickými kruhmi, na ktorej boli na spodnej časti zachytené železné nity na prichytenie na podklad (obr. 1:2). V prípade druhého predmetu išlo o hrot šípu (obr. 1:1). Analogická doštička sa našla aj na král'ovskom Pustom hrade vo Zvolene, ktorý je s hradom Pet’uša vo vizuálnom kontakte a vzdušná vzdialenost' medzi nimi predstavuje niečo vyše $2 \mathrm{~km}$ (Beljak et al. 2014, 199). Výnimočný je hlavne kostený hrot šípu s unikátnym tvarom. Celkovo sa takýto prameň objavuje len zriedkavo. Jeden poznáme zo zvolenského Pustého hradu (Hanuliak 1999, tab. 6:9; Šimkovic-Beljak-Maliniak 2011, obr. 25) a d’alší bol objavený v Chl'abe, v tomto prípade však so skorším datovaním do 10. storočia (Hanuliak 2016, tab. X:14). Hrot šípu nájdený na hrade Pet’uša je podobný typu 1 podl'a Medvedeva, ktorý nemá odčlenenú tul'ajku od hrotu a je datovaný prevažne do vrcholného stredoveku (Medvedev 1966, tab. 30:130).

\section{Vyhodnotenie}

Analyzovaný súbor z hradu Pet'uša, datovaného od konca 13. do prelomu 15. a 16. storočia, sa vyznačuje bohatou biodiverzitou. Materiál bol spracovaný anatomicko-taxonomickou analýzou, zameranou predovšetkým na určenie druhov, ich anatomických častí a na stopy po l'udskej aktivite (sekanie, rezanie, pílenie, polotovary a pod.), ako aj na stopy po pôsobení žiaru.

Archeozoologická analýza doložila dva primárne, ale i sekundárne zdroje mäsitej zložky potravy obyvatel'ov hradu. Lokálnu ekonomiku zastupujú hlavne domáce a divé druhy.

Domáce druhy tvorili približne 68 \% z identifikovaných jedincov. Najpočetnejšie z hladiska počtu kostí boli z domácich zvierat zastúpené ovce/kozy (vrátane identifikovanej ovce a kozy, $24,3 \%$ ), ošípaná $(22,6 \%)$ a hovädzí dobytok (15,2\%). Kura domáca bola zastúpená $5 \%$.

Značnú diverzitu predstavovala divá zver (až 20,4\% z identifikovaných druhov). Prevládali fragmenty kostí z jeleňa $(16,6 \%)$, objavil sa však aj srnec $(2,2 \%)$ či diviak $(0,3 \%)$. Okrem vysokej a čiernej zveri tu boli doložené aj kožušinové druhy, ako medved' hnedý, zajac pol'ný, veverička hrdzavá, ale i mačka divá. To nám dokladá, že na hrade nelovili zvieratá len na mäso, ale pravdepodobne i na kožušinu. Od arpádovského obdobia poznáme v regióne viaceré správy o prítomnosti král'ovských strážcov lesa - hájnikov, avšak priame údaje o love konkrétnych druhov zveri spočiatku chýbajú (Maliniak 2015, 395). Medzi prvými údajmi o love divej zveri a jeho ekonomickom zhodnocovaní (uplatnení aj v odievaní) vystupuje do popredia od konca 13. storočia kožušinová zver, hlavne kuna, ale spomínajú sa aj veveričie kožušiny (Maliniak 2015, 402). 

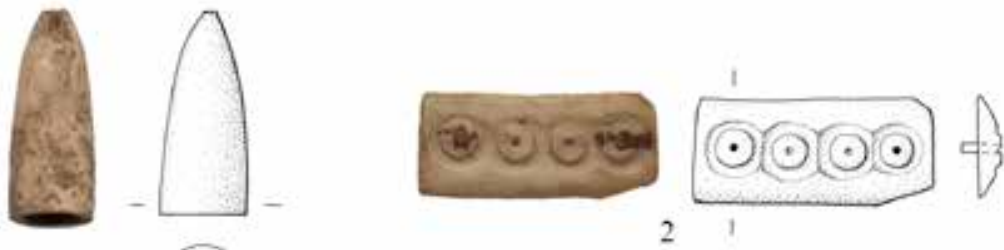

1
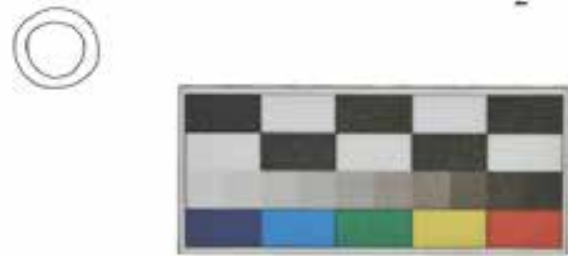

a
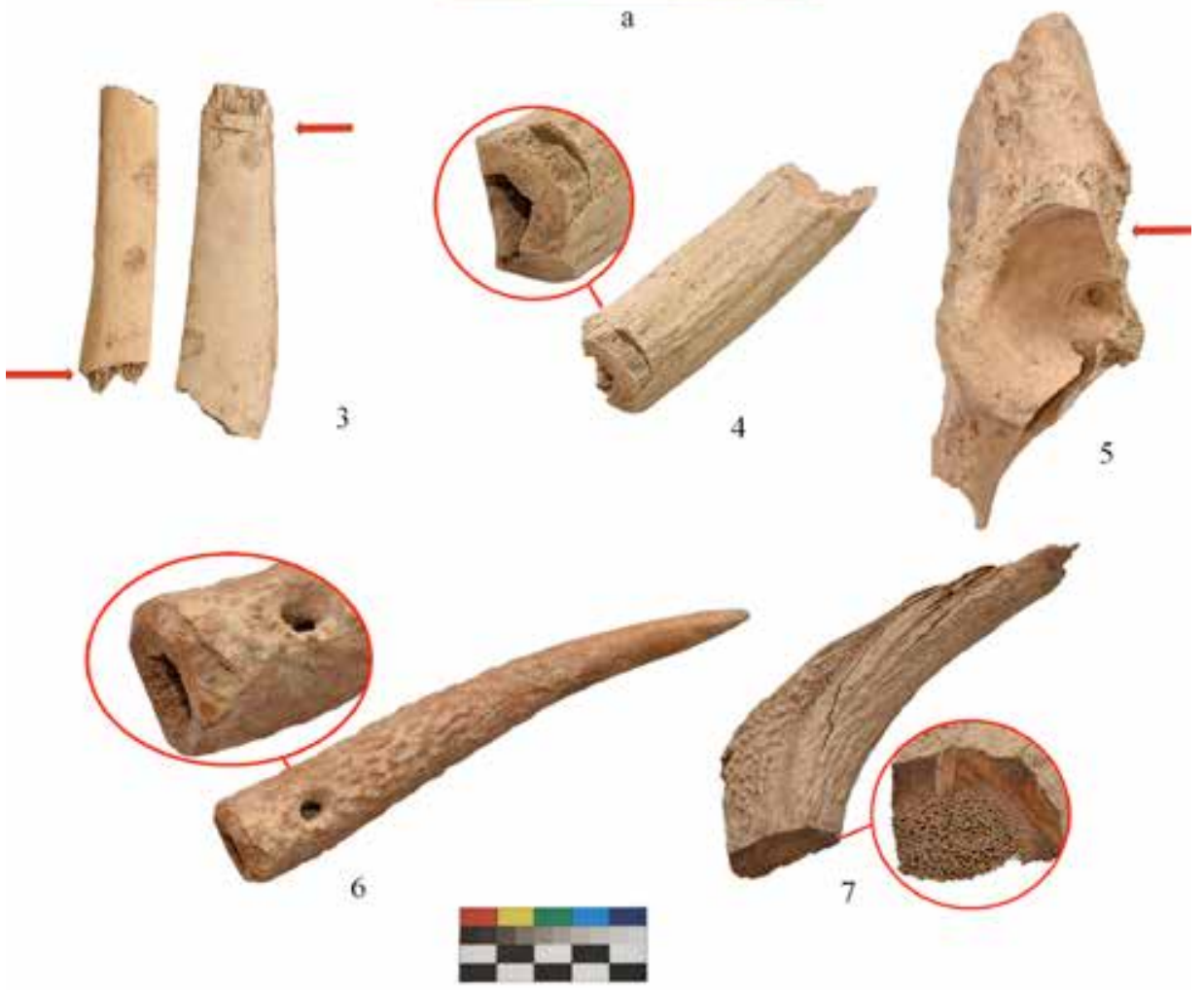

b

Obr. 1. Hrad Pet’uša. Kostené predmety, polotovary a stopy po sekaní na kostiach; mierka a - 1, 2; mierka b-3-7. Kresba D. Zeleňáková, foto M. Styk.

Abb. 1. Burg Pet'uša. Gegenstände aus Bein, Halbprodukte und Hackspuren an Knochen; Maß a-1, 2; Maß b-3-7. Zeichnungen D. Zeleňáková, Foto M. Styk. 
Rybolov sa v archeozoologickom materiáli podarí bez preplavovania doložit' len sporadicky. V našom prípade tento zdroj obživy reprezentuje len 11 kostí, pričom konkrétny druh rýb sa identifikovat' nepodarilo. Odchytávané mohli byt' priamo v blízkej rieke Hron, tečúcej okolo hradu z východnej a severnej strany. V dobových prameňoch z neskorého stredoveku a začiatku novoveku sa stretávame aj s konkrétnymi druhmi rýb. Spomínajú sa napríklad vyzy (tie boli zrejme dovážané z juhu) a tiež pstruhy, karasy, št’uky a kapry (Maliniak 2009, 175, 176; 2015, 400).

Málo poznatkov sa z archeozoologického materiálu darí získat' o domácich zvieratách, ktoré neboli chované na mäso, ako sú pes a kôň. Na hrade Pet'uša boli objavené len sporadické fragmenty kostí týchto zvierat, v prípade psa aj horná čel'ust', avšak bez zubov. Na týchto kostiach sa nezachytili stopy po l'udskej činnosti a len na jednej kolennej kosti psa boli zaznamenané stopy po pôsobení ohňa (opálenie dohneda). V tomto prípade mohlo íst' aj o sekundárny zásah pôsobením ohňa pri požiari na hrade. Zistená kohútiková výška jedného zo psov, ktorá len málo prevyšuje $31 \mathrm{~cm}$, vypovedá o psovi menšieho vzrastu, ktorý je bežnejší v arpádovskom období Uhorska, pričom v neskoršom období sa výška postupne zväčšuje (Tassi 2002).

Identifikované druhy vtákov nám pomohli nahliadnut' do ekológie okolitej krajiny. Nachádzali sa tú druhy typicky lesné, ako hlucháň hôrny, ale taktiež aj druhy bežne sa vyskytujúce na kultúrnych stepiach (napr. jarabica pol’ná, bažant obyčajný; Peške 1981, 146-150). Písomné pramene sa zmieňujú o vtáčnictve v okolí Zvolenskej župy, pričom v mestských účtoch zo Zvolena z roku 1501 sa spomínajú hlavne kurence a jarabice (Maliniak 2009, 187; 2015, 400).

Opomenút' nemožno ani identifikovanie niekol'kých hlodavcov, a to potkana a plcha záhradného. Plch záhradný je jeden z najpestrejších plchov a dnes je zákonom chránený. S obl'ubou sa drží v kamenných sutinách, ruinách, na lesných pasienkoch a medziach s kameňmi (KorbelKrejča 1981, 314; Anděra-Horáček 2005, 156).

Na lokalite sa našli v kultúrnych vrstvách i ulitníky, z ktorých boli určené dva druhy, bacul'ka obyčajná a slimák záhradný, a čel’ad' vretienkových slimákov. Slimák záhradný žije predovšetkým v teplých polohách, hájoch a, samozrejme, v záhradách; bacul'ka obyčajná v krovinách a hájoch, ale najradšej na mokrých miestach. Najviac nájdených ulít patrilo predovšetkým do čelade vretienkových slimákov, pre ktoré je typický lesný porast a ktoré sa držia hlavne pri kmeňoch alebo na skalách (Korbel-Krejča 1981, 62).

Práve tieto druhy divej zveri, či už ide o vysokú, čiernu, kožušinovú zver, vtáky alebo ulitníky a hlodavce, nám poukazujú, že v období vrcholného stredoveku bol podobne ako v súčasnosti v okolí hradu listnatý les s miernym podnebím a kultúrna step vo forme polí a pasienkov.

O spracovaní mäsa svedčia stopy po sekaní a rezaní nielen na dlhých kostiach, ale aj na stavcoch a lebkách, takže tu môžeme pozorovat' nielen zásahy kuchynského charakteru, ale taktiež mäsiarskeho, čiže porciovanie mäsa na väčšie kusy. Pokial' ide o stopy po pôsobení ohňa, sú doložené na viacerých druhoch. Tu je však otázne, či kosti boli opálené prvotným spôsobom pri úprave potravy, prípadne pri spal’ovaní odpadu, alebo to súvisí so sekundárnym prepálením, ked’že množstvo týchto kostí sa našlo v zánikovom horizonte popolovitej vrstvy identifikovanej na nádvorí hradu. Sfarbenie kostného tkaniva nám poukazuje na teploty od $285^{\circ} \mathrm{C}$ až do viac ako $940{ }^{\circ} \mathrm{C}$. Divé zvieratá však neboli určené len výlučne na stravu, ale slúžili aj ako surovina na spracovanie kostených predmetov. Bol tu doložený odpad zo spracovania parohoviny vo forme odštiepkov z parohov, prípadne polotovary, ktoré nesú na sebe známky pílenia, rezania či sekania (obr. 1:3-7). Na hrade Pet'uša sa našli aj dva drobné predmety, a to kostená doštička zdobená koncentrickými kruhmi (obr. 1:2) a kostený hrot šípu (obr. 1:1).

Informácie o kvalite mäsa, ktorú reprezentujú určité anatomické časti skeletu, nemáme zo stredovekých hradov na Slovensku zatial' dostatočne zachytené. Ako porovnanie vieme však aplikovat' údaje zo stredovekého mesta Glanzenberg v Banskej Štiavnici (Bielichová-Labuda 2017, 39). Podobná je hlavne kvalita mäsa u hovädzieho dobytka, pričom na oboch lokalitách prevažuje kategória kvality C. Na rozdiel od hradu Pet'uša bolo na Glanzenbergu bravčové mäso zastúpené hlavne v kategórii kvality mäsa B a A. Na hrade Pet'uša bola zo svine domácej výrazne zastúpená kategória $\mathrm{C}$ (až $64 \%$ ). Evidentné rozdiely sú aj u ovce/kozy. U tohto druhu sú 
na hrade Pet'uša pomerne rovnocenné všetky kategórie $(A=28,1 \%, B=39 \%, C=32,9 \%)$, no v Glanzenbergu výrazne prevažuje kategória B (62,5\%). To nám poukazuje na značné rozdiely v kvalite mäsa požívaného v stredovekom meste Glanzenberg a na analyzovanom vrcholnostredovekom hrade Pet'uša.

Vo všeobecnosti môžeme povedat', že na hrade Pet'uša absolútne prevláda odpadová/jatočná kategória kvality mäsa C (až 53 \%). Podobné zloženie môžeme vidiet' napríklad v analýze zo zaniknutej stredovekej dedine Konůvky (okr. Vyškov), kde prevažuje kvalita C (54,3\%), nasledovaná kvalitou B (31,9\%). Na tej istej lokalite, no v súbore z tvrdze, je kvalita mäsa B zastúpená 45\%, kvalita mäsa C 34,9\% a kategórie A 20,1 \% (Páral-Měchurová-Riedlová 1995, 421). Naopak, napríklad na hrade Lelekovice (okr. Brno-venkov) kvalita A dosahuje 35,1 \% (PáralRiedlová-Unger 1994, 201). Toto zistenie podporuje domnienku, že hrad Pet'uša nemal funkciu šlachtického sídla, no slúžil ako strážny hrad, na ktorom bola posádka zásobovaná predovšetkým „horším“ mäsom.

Publikované analýzy zvieracieho osteologického materiálu z hradov z územia Slovenska sú vel'mi skromné. K dispozícii máme údaje napríklad z hradu Lietava (Bielich 2015; Vozák 2014), hradu Gýmeš (určil Z. Vozák; Bielich-Elgyütt 2015), Oponického hradu (Repka-Sater-Šimunková 2017) a hradu Dobrá Niva (Šimunková-Beljak Pažinová 2017), ide však o lokality, resp. nálezové celky, datované prevažne do 15. až 17. storočia. Aj z tohto dôvodu nie je možné podat' relevantné porovnanie nálezov z hradu Pet’uša s ostatnými hradmi a regiónmi z územia Slovenska. Napriek týmto výhradám sa pokúsime len ilustračne načrtnút' stav archeozoologických výsledkov na slovenských hradoch. Hrad Pet’uša zaujíma na základe výpovede zvieracích kostí osobitné postavenie $\mathrm{v}$ rámci spomínaných hradov, a to predovšetkým svojím podielom domácich a lovených druhov. Domáce druhy tu tvoria $64 \%$, pričom na ostatných hradoch (neskoršie datovaných) je percentuálne zastúpenie 92-97\%. Rozdiely sú pozorovatel'né aj v zastúpení jednotlivých druhov. Tur domáci zastupuje na hrade Pet'uša 15,2\%, pričom najbližšie k tomuto údaju je hrad Lietava s desatinným podielom tohto druhu. Na ostatných hradoch sa pohybuje od 32-44\% (hrad Dobrá Niva a Oponický hrad). Kategória ovce a kozy (vrátane obidvoch druhov) je pomerne rovnako zastúpená ako na ostatných hradoch, ktoré kulminujú okolo $25 \%$ (len na hrade Dobrá Niva je toto percento vyššie a dosahuje 30\%). To isté platí aj u svine domácej, ktorá je na hrade Pet’uša zastúpená $22,6 \%$. Rozdiel je markantný v porovnaní s hradom Lietava, kde tvorí len $10 \%$. Evidentný rozdiel je aj v pomeroch lovnej zveri. Na hrade Pet'uša dosahuje výskyt až okolo $20 \%$, pričom na ostatných hradoch tvorí divá zver podiel približne do $10 \%$. V lovených druhoch prevažuje vysoká lovná zver, ale nájdeme tu i diviaka lesného, medved’a hnedého či zajaca a mačku divú.

Vzhl’adom na vekové kategórie zvierat, kvalitu mäsa i druhové zloženie je možné uviest', že obyvatelia hradu Pet’uša mali v strave predovšetkým staršie jedince, hlavne ovce a kozy, ošípanú a na poslednom mieste tura domáceho. Mäso malo zároveň nižšiu kvalitu.

Jelene sa lovili aj za účelom istého druhu remeselnej výroby, čo nám dokladajú polotovary a odpad zo spracovania parohoviny. Okrem toho sa na hrade našli kosti aj z kožušinovej zveri (medved' hnedý, zajac pol’ný, veverička hrdzavá, ale i mačka divá), čo by mohlo naznačovat', že tieto druhy sa nelovili len pre mäso, ale pravdepodobne skôr na kožušinu.

Z vyššie spomínaných informácií je možné povedat', že hrad Pet’uša má svojbytné postavenie v rámci vrcholnostredovekých hradov územia Slovenska. Archeozoologickou analýzou sa poukázalo na rozdiely v skladbe druhov i kvalite mäsa od šlachtických hradov, pričom porovnatel'né údaje nám vykazuje mestské a dedinské prostredie stredoveku. Z tohto hladiska sa môžeme priklonit' $\mathrm{k}$ názoru, že hrad obývala vojenská posádka, ktorá mala nižšie nároky na mäsitú zložku stravy. 


\section{Literatúra}

ADAMS, B. J.-CRABTREE, P. J., 2008: Comparative Skeletal Anatomy. A Photographic Atlas for Medical Examiners, Coroners, Forensic Anthropologists, and Archaeologists. Totowa.

ANDĚRA, M.-HORÁČEK, I., 2005: Poznáváme naše savce. 2. přepracované vydání. Praha.

BELJAK, J. et al., 2014: Pustý hrad vo Zvolene, Dolný hrad 2009-2014. Zvolen - Nitra.

BELJAK PAŽINOVÁ, N., 2017: Vrcholnostredoveký hrad Pet'uša - Die mittelalterliche Burg Pet'uša und ihre postmediävale Nutzung, AH 42, 607-621.

BELJAK PAŽINOVÁ, N.-RAGAČ, R., 2018: Hrad Pet'uša - šlachtické sídlo alebo mýtna stanica? Konfrontácia archeologických a historických prameňov - Die Burg Pet'uša - Adelssitz oder Mautstation? Eine Konfrontation von archäologischen und historischen Quellen, AH 43, 61-75.

BIELICH, M., 2015: Archeologický výskum Lietavského hradu v rokoch 2012-2013: piata a šiesta výskumná sezóna - Die archäologische Grabung auf der Burg Lietava in den Jahren 2012-2013: fünfte und sechste Grabungssaison, AH 40, 115-129.

BIELICH, M.-ELGYÜTT, J., 2015: Archeologický výskum hradu Gýmeš v rokoch 2013-2014 - Die archäologischen Grabungen auf Burg Gýmeš in den Jahren 2013-2014, AH 40, 597-611.

BIELICHOVÁ, Z.-LABUDA, J., 2017: Nálezy zvieracích kostí z výskumu Glanzenbergu tzv. Starého mesta v Banskej Štiavnici, Zborník Slovenského banského múzea 25, 30-69.

BOESSNECK, J., 1969: Osteological differences between sheep (Ovis aries Linné) and goat (Capra hircus Linné). In: Science in Archaeology: A comprehensive survey of Progress and Research (Brothwell, D. R.-Higgs, E. D., edd.), 311-358. London.

BOCHEŃSKI, Z.-TOMEK, T., 2000: The comparative osteology of European corvids (Aves: Corvidae): with a key to the identification of their skeletal elements. Kraków.

- 2009: A key for the identification of domestic bird bones in Europe. Preliminary determination. Kraków.

- 2009a: A key for the identification of domestic bird bones in Europe. Galliformes and Columbiformes. Kraków.

DOLL, M., 2003: Haustierhaltung und Schlachtsitten des Mittelalters und der Neuzeit: eine Synthese aus archäozoologischen, bildlichen und schriftlichen Quellen Mitteleuropas. Rahden/Westfalen.

von den DRIESCH, A., 1976: Das Vermessen von Tierknochen aus Vor- und Frühgeschichtlichen Siedlungen. München.

von den DRIESCH, A.-BOESSNECK, J., 1974: Kritische Anmerkungen zur Widerristhöhenberechnung aus Langenmassen vor- und frühgeschichflicher Tierknochen, Saugetierkundliche Mitteilungen 22, 325-348.

FRANCE, S. L., 2009: Human and Nonhumane Bone Identification. A color atlas. Boca Raton.

GRANT, A., 1982: The use of tooth wear as a guide to the age of domestic ungulates. In: Ageing and sexing animal bones from archaeological sites (Wilson, B.-Grigson, C.-Payne, S., edd.), 91-108. Oxford.

HALSTEAD, P.-COLLINS, P., 1995: Sheffield animal bone tutorial: Taxonomic identification of the principal limb bones of common European farmyard animals and deer: a multimedia tutorial. Glasgow.

HALSTEAD, P.-COLLINS, P.-ISAAKIDOU, V., 2002: Sorting the sheep from goats: Morphological distinctions between the mandibles and mandibular teeth of adult Ovis and Capra, Journal od Archaeological Science 29, 545-553. https://doi.org/10.1006/jasc.2001.0777

HANULIAK, M., 2016: Sídliská z 8.-10. storočia v Chl’abe, S1Arch LXI, 95-144.

HANULIAK, V., 1999: Doklady hmotnej kultúry Starého Zvolena (Pustého hradu) od 12. do 17. storočia, AH 24, 352-361.

HARCOURT, R. A., 1974: The dog in prehistoric and early historic britain, Journal of Archaeological Science 2/1, 151-175. https://doi.org/10.1016/0305-4403(74)90040-5

HILLSON, S., 2005: Teeth. Cambridge.

KLEIN, R. G.-CRUZ-URIBE, K., 1984: The analysis of Animal Bones from Archeological Sites. Prehistoric Archaeology and Ecology Series. Chicago.

KOLDA, J., 1951: Osteologický atlas. Praha.

KORBEL, L.-KREJČA, J., edd., 1981: Z našej prírody. Živočíchy prvé. Bratislava.

KYSELÝ, R., 2004: Kvantifikační metody v archeozoologii, AR LVI, 279-296.

MALINIAK, P., 2009: Človek a krajina Zvolenskej kotliny v stredoveku. Banská Bystrica. 
MEDVEDEV, A. F., 1966: Ručnoe metal'noje oružije VIII.-XIV. v. Archeologija SSSR. Moskva.

- 2015: Úlovky, dary a jelene v maštali. Sociálne a kultúrne pozadie polovníctva vo Zvolenskej stolici. In: Dvořáková, D. a kol., Človek a svet zvierat v stredoveku, 393-408. Bratislava.

NÝVLTOVÁ FIŠÁKOVÁ, M.-PROCHÁZKA, R.-SŮVOVÁ, Z., 2016: Vyhodnocení osteologických pozůstaků z výzkumu parcel domů Dominikánská 11-19 a Kobližná 3 v Brně. K otázce organizace zásobování měst masem ve vrcholném středověku, PV 57, č. 2, 95-176.

PÁRAL, V.-MĚCHUROVÁ, Z.-RIEDLOVÁ, M., 1995: Zvířecí kosti ze zaniklé středověké vsi Konůvky (okr. Vyškov) - Tierknochen aus dem niedergegangenen Dorf Konůvky, AH 20, 417-425.

PÁRAL, V.-PYSZKO, M., 2011: Kosti ze středověké kuchyně, Anthropologia integra 2, č. 2, 19.

PÁRAL, V.-RIEDLOVÁ, M.-UNGER, J., 1994: Zvířecí kosti z hradu Lelekovice (okr. Brno-venkov) Tierknochen aus der Burg Lelekovice, Kreis Brno-Land, AH 19, 199-205.

PAYNE, S., 1973: Kill-off patterns in sheep and goats: the mandibles from Asvan Kale, Anatolian Studies 23, 281-303. https://doi.org/10.2307/3642547

- 1987: Reference codes from wear states in the mandibular cheek teeth of sheep and goats, Journal of archaeological Science 14, 609-614. https://doi.org/10.1016/0305-4403(87)90079-3

PEŠKE, L., 1981: Ekologická interpretace holocenní avifauny Československa. Holocenní avifauna jako zdroj informací o typech krajiny v různých obdobích, AR XXXIII, 142-153.

POPESKO, P., 2007: Atlas topografickej anatómie hospodárskych zvierat. I.-III. diel. Bratislava.

REITZ, E. J.-WING, E. S., 2008: Zooarchaeology. Cambridge.

REPKA, D.-SATER, P.-ŠIMUNKOVÁ, K., 2017: Archeologické nálezy z Oponického hradu. Rozbor nálezov získaných počas sanácie hradu v rokoch 2001-2014 a archeologického výskumu v rokoch 2015-2016, ŠZ AÚ SAV 62, 181-204.

SHIPMAN, P.-FOSTER, G.-SCHOENINGER, M., 1984: Burnt bones and teeth: an experimental study of color, morphology, crystal structure and shrinkage, Journal of archaeological science 11, 307-325.

SCHMID, E., 1972: Atlas of Animal Bones. For Prehistorians, Archaeologists and Quaternary Geologist. Amsterdam - London - New York.

ŠIMKOVIC, M.-BELJAK, J.-MALINIAK, P., 2011: Zvolenský Pustý hrad. Sprievodca po hrade. Zvolen.

ŠIMUNKOVÁ, K.-BELJAK PAŽINOVÁ, N., 2017: Konzumácia mäsa na hradoch v novoveku. Prípadová štúdia z hradu Dobrá Niva - Der Fleischkonsum in der Neuzeit auf Burgen. Eine Fallstudie von Burg Döbring, AH 42, 511-521.

TASSI, M., 2002: Kutyák a középkori Magyarországon. Szakdolgozat. Eötvös Loránd Tudományegyetem. Budapest.

TEICHERT, M., 1969: Osteometrische Untesuchungen zur Berechnung der Widerristhöhe bei vor- und frühgeschichtlichen Schweinen, Kühn-Archiv 83, 237-292.

THURZO, M.-BEŇUŠ, R., 2005: Základy tafonómie hominidov a iných stavovcov. Bratislava.

VITT, O., 1952: Lošadi Pazyrykskich kurganov - Die Pferde der Kurgane von Pazyryk, Sovetskaja Archeologija 16, 163-205.

VOZÁK, Z., 2014: Archeozoologická analýza nálezov z Lietavského hradu z rokov 2008-2010. In: Hrad Lietava 2003-2013, 10-103. Lietava.

ZOETIS, T.-TASSINARI, M. S.-BAGI, C.-WALTHALL, K.-HURTT, M. E., 2003: Species comparison of postnatal bone growth and development. Birth Defects Research Part B, Developmental and Reproductive Toxicology 68, č. 2, 86-110. https://doi.org/10.1002/bdrb.10012

\section{Zusammenfassung}

\section{Der Fleischkonsum im Hochmittelalter auf Burgen: Eine Fallstudie von Burg Pet'uša}

Der analysierte, von der auf Burg Pet'uša in den Jahren 2011-2017 durchgeführten Grabung stammende und in die Zeit zwischen Ende des 13. bis zur Wende des 15./16. Jahrhunderts datierte Fundkomplex zeichnet sich durch eine reiche Biodiversität aus (Tabelle 1). Das Material wurde anhand einer anatomisch-taxonomischen Analyse ausgewertet, die vor allem auf die Bestimmung der Arten, ihrer anatomischen Teile sowie auf Spuren von menschlichen Aktivitäten, 
als auch auf Spuren von Hitzeeinwirkung ausgerichtet war. Die osteologischen Überreste bestanden aus insgesamt 6791 Fragmenten mit einer Masse von ungefähr 49,3 kg.

Heimische Arten (Diagramm 1) stellten annähernd $68 \%$ der identifizierten Individuen dar. Bezüglich der Anzahl der Knochen waren an Haustierarten Schaf/Ziege (identifizierte Schafe und Ziegen zusammen 24,3 \%), Hausschwein (22,6\%) und Hausrind (15,2\%) am häufigsten vertreten. Das Haushuhn war mit $5 \%$ vertreten.

Eine beträchtliche Diversität stellte Wild dar (bis zu 20,4\% der identifizierten Arten). Es überwogen Knochenfragmente vom Hirsch (16,6\%), es kam jedoch auch Reh (2,2\%), bzw. Wildschwein $(0,3 \%)$ vor. Neben Hochwild und Schwarzwild waren dort auch Haarwildarten wie der Braunbär, Feldhase, das Eichhörnchen aber auch die Wildkatze vertreten. Das belegt, dass man auf der Burg Tiere nicht nur wegen ihres Fleisches, sondern wahrscheinlich auch ihrer Felle wegen gejagt hat.

Fischfang läßt sich im archäozoologischen Material ohne Schlämmen nur sporadisch belegen. In unserem Fall wird diese Nahrungsquelle nur durch 11 Gräten und durch Schuppen repräsentiert, wobei keine konkrete Fischart identifiziert werden konnte. Gefangen werden konnten Fische direkt im nahegelegenen Fluss Gran, der die Burg an der Ost- und Nordseite umfließt.

Fragmente von Hunde- und Pferdeknochen wurden auf Burg Pet'uša nur sporadisch gefunden. An diesen Knochen konnten keine Spuren einer menschlichen Tätigkeit entdeckt werden, lediglich an dem Kniebein eines Hundes waren Spuren von Hitzeeinwirkung (bräunlich verkohlt) erkennbar. In diesem Fall könnte dies auch auf eine sekundäre Hitzeeinwirkung bei einem Brand auf der Burg zurückzuführen sein.

In den Proben wurden auch verschiedene Wildvogelarten identifiziert. Es befanden sich dort typische Waldvogelarten wie der Auerhahn, ebenso aber auch Arten, die in Kultursteppen vorkommen (z.B. Rebhuhn, Fasan).

Vergessen werden darf auch nicht die Identifizierung einiger Nagetiere, und zwar der Wanderratte und des Gartenschläfers, ferner fanden sich in den Kulturschichten der Fundstätte auch Schalentiere, von denen zwei Arten bestimmt wurden, die der Strauchschnecken und Weinbergschnecken sowie die Familie der Schließmundschnecken.

Auf die Verarbeitung von Fleisch weisen nicht nur Hack- und Schnittspuren an langen Knochen hin, sondern auch an Wirbeln und Schädeln, sodass man hier nicht nur Eingriffe beobachten kann, die den Charakter von Tätigkeiten in einer Küche, sondern auch die eines Fleischers aufweisen, wie das Portionieren von Fleisch zu größeren Stücken (Diagramm 4). Was Spuren einer Hitzeeinwirkung anbelangt, sind solche auf mehrere Art und Weisen belegt. Hier ist jedoch fraglich, ob die Knochen primär bei der Zubereitung der Nahrung, ggf. beim Verbrennen des Abfalls angesengt wurden, oder ob dies sekundär erfolgte, da eine Fülle dieser Knochen im Untergangshorizont der im Burghof identifizierten Aschenschicht gefunden wurden. Die Verfärbung des Knochengewebes indiziert Temperaturen im Bereich von $285^{\circ} \mathrm{C}$ bis über $940{ }^{\circ} \mathrm{C}$ (Diagramm 5). Wild war jedoch nicht ausschließlich für die Ernährung bestimmt, sondern diente auch als Rohstoff für die Verarbeitung von Gegenständen aus Bein. Hier war Abfall aus der Verarbeitung von Geweihen in Form von Geweihsplittern, ggf. halbfertige Produkte belegt, die Feil-, Schneide- oder Hackspuren aufweisen (Abb. 1:3-7). Auf Burg Pet'uša fand man auch zwei kleine Gegenstände, und zwar ein mit konzentrischen Kreisen verziertes Täfelchen (Abb. 1:2) und eine Pfeilspitze aus Bein (Abb. 1:1).

Hinsichtlich der Alterskategorie der Tiere (Diagramm 2), der Fleischqualität (Diagramm 3; bis zu 53\% Abfall-/Schlachtkategorie der Fleischqualität C) sowie der Artenzusammensetzung kann man sagen, dass die Kost der Bewohner von Burg Pet'uša vor allem aus älteren Individuen bestand, besonders aus Schafen und Ziegen, Hausschweinen und an letzter Stelle aus Hausrindern. Das Fleisch war gleichzeitig von geringerer Qualität. In dieser Hinsicht können wir zu der Auffassung tendieren, dass die Burg von einer Militärgarnison bewohnt wurde, deren Ansprüche an die Fleischkomponente der Ernährung niedriger waren. 
Der vorliegende Beitrag wurde von der Forschungs- und Entwicklungsagentur unter der Vertragsnr. APVV-0063-17 Vita intra muros - Interdisziplinäre Erforschung der Burgen der Mittelslowakei gefördert.

doc. PhDr. Noémi Beljak Pažinová, PhD., Katedra archeológie Filozofickej fakulty Univerzity Konštantína Filozofa v Nitre, Hodžova 1, SK 94901 Nitra, Slovenská republika,nbpazinova@ukf.sk

Mgr. Katarína Šimunková, Katedra archeológie Filozofickej fakulty Univerzity Konštantína Filozofa v Nitre, Hodžova 1, SK 94901 Nitra, Slovenská republika, katarina.simunkova@gmail.com 
